\begin{tabular}{lllll} 
Abstract 731 Table 1 & & \\
\hline & Total & MMRd $(n=5)$ & NSMP (n=10) & p53abn (n=23) \\
\hline PFS rate at 6m (95\%Cl) & $59 \%(45-78)$ & $53 \%(21-100)$ & $78 \%(55-100)$ & $52 \%(35-77)$ \\
Median PFS & 6.5 months & 6.2 months & 10.3 months & 6.4 months \\
ORR & $32 \%$ & $40 \%$ & $40 \%$ & $26 \%$ \\
OS rate at 18m & $51 \%$ & $25 \%$ & $74 \%$ & $49 \%$ \\
Median OS & 18.5 months & 11.9 months & Not reached & 14.8 months \\
\hline
\end{tabular}

were analysed before treatment. Immunohistochemistry was performed for mismatch repair proteins and $\mathrm{p} 53$. Single-gene sequencing was used to detect polymerase- $\mathrm{C}$ (POLE) exonuclease domain mutations. Primary outcome was progressionfree survival rate at 6 months (PFS6). Subgroups were assessed relative to the primary outcome, ORR, median overall survival (OS), and 18-months OS rate.

Result(s)* Molecular classification could be determined in 44 out of 48 patients included. As defined in the protocol, carcinosarcoma patients $(n=6)$ were considered an exploratory cohort and were excluded from this analysis. In the non-carcinosarcoma cohort $(\mathrm{n}=38)$ median age was 66 years (range 37-80). Five (11.4\%) patients were MMRd, 10 (22.7\%) NSMP and $23(52.3 \%)$ p53abn. No patient with POLEmutated tumour was enrolled. Fifty-eight patients had endometroid EC, $42 \%$ serous carcinoma. Histologic grade at diagnosis: grade $1,12.2 \%$; grade $2,21.1 \%$ and grade $3,44.6 \%$. Median follow-up at data cut-off was 19.1 months. Overall PFS6 was 59.3\% (95\%CI 45.4\%-77.6\%) with a median PFS of 6.5 months. Efficacy data according to patients' molecular subtype are shown (see table 1). Overall, the NSMP subtype showed the better efficacy results (PFS6 of $78 \%$ and $40 \%$ ORR).

Conclusion* Pembrolizumab plus doxorubicin exhibited promising antitumor activity in women with advanced EC after failure to platinum therapy, even in those patients that were not MMRd.

\section{THE CLINICAL IMPACT OF MSI AND DMMR IN ADVANCED ENDOMETRIAL CANCER: THE EFFECT OF ONLINE EDUCATION ON CLINICIAN KNOWLEDGE, COMPETENCE AND CONFIDENCE}

\footnotetext{
1;2 G Fisher*, ${ }^{2} \mathrm{~A}$ Furedy, ${ }^{2} \mathrm{~J}$ Vandenbroucque, ${ }^{3} \mathrm{C}$ Marth. ${ }^{1}$ Medscape Education Global, UK;
} ${ }^{2}$ Medscape Education Global, London, UK; ${ }^{3}$ Innsbruck Medical University, Innsbruck, Austria

\subsection{6/jgc-2021-ESGO.188}

Introduction/Background* This study determined whether online continuing medical education (CME) could improve the knowledge of obstetricians/gynaecologists (obs/gyns) and oncologists (oncs) regarding the relevance of Microsatellite Instability (MSI) and deficient Mismatch Repair (dMMR) for immunotherapy paradigms in advanced endometrial cancer, and increase competence in terms of the application of appropriate diagnostic testing.

Methodology A 15-minute online video discussion between two expert faculty was launched for physicians outside the USA October 2020 with data collected to March 2021. Educational effect assessed with repeated-pairs pre-/post-activityindividual participants serving as their own control. 3 multiple-choice, knowledge questions and 1 self-efficacy, 5-point
Likert scale confidence question were analysed. McNemar's test assessed pre- to post-activity change (5\% significance level, $P$ <.05). Magnitude of change in total number of correct responses overall, and for each question, determined with Cohen's d $(<.2=$ Modest, .20-.49=Small, . $50-.79=$ Moderate, $>.80=$ Large.

Result(s)* 393 obs/gyns and 73 oncs completed pre- and postactivity questions. Positive educational effect was observed for obs/gyns (moderate effect, Cohen's $\mathrm{d}=.78, \mathrm{P}<.001$; average $\%$ of correct responses increasing from 43 to 67\%) and oncs (large effect, Cohen's $\mathrm{d}=.88, \mathrm{P}<.001$; average $\%$ of correct responses increasing from 57 to $80 \%$ ). Increases in correct responses post-activity were seen for questions on features of dMMR (\% relative improvement, obs/gyn: 37\%, oncs 25\%), appropriate diagnostic testing (obs/gyns: 17\%, oncs: 13\%), and frequency of dMMR (obs/gyns: 188\%, oncs: 133\%). The $\%$ of participants answering all questions correctly increased from 7 to $30 \%$ for obs/gyns and from 16 to $53 \%$ for oncs. Pre-activity knowledge for both specialties was low on the features and frequency of $\mathrm{dMMR}$ and despite significant improvements, there remained room for improvement postactivity. Confidence in understanding the relevance of dMMR in advanced endometrial cancer increased post-activity with $63 \%$ of obs/gyn and $48 \%$ of oncs with improved confidence. Overall, 63\% of obs/gyns and $60 \%$ of oncs improved their knowledge and competence by answering at least one more question correctly post-activity.

Conclusion* This on-demand, online video discussion resulted in a positive educational impact. However, education gaps remain evident. Online medical education is valuable in supporting the implementation of new diagnostic strategies into clinical practice as well as identifying areas of continued educational need.

\section{TUMOR CELL DISSEMINATION IS INDEPENDENT FROM ENDOMETRIAL CARCINOMA MOLECULAR SUBTYPES}

${ }^{1} \mathrm{~L}$ Volmer*, ${ }^{2} \mathrm{~S}$ Kommoss, ${ }^{1} \mathrm{C}$ Walter, ${ }^{3} \mathrm{~J}$ Mcalpine, ${ }^{4} \mathrm{~A}$ Lum, ${ }^{3} \mathrm{~A}$ Talhouk, ${ }^{1} \mathrm{~S}$ Matovina, ${ }^{1} \mathrm{~T}$ Engler, ${ }^{1} \mathrm{M}$ Grube, ${ }^{1} \mathrm{M}$ Weiss, ${ }^{5} \mathrm{~A}$ Staebler, ${ }^{1} \mathrm{~A}$ Koch, ${ }^{1} \mathrm{~A}$ Hartkopf. ${ }^{1}$ Tübingen University hospital, Department of Women's health, Tuebingen, Germany; ${ }^{2}$ Tuebingen University Hospital, Department of Women's Health, Tuebingen, Germany; ${ }^{3}$ University of British Columbia, Department of Gynecology and Obstetrics, Division of Gynecologic Oncology, Vancouver, Canada; ${ }^{4} B C$ Cancer Research Centre, Department of Molecular Oncology, Vancouver, Canada; ${ }^{5}$ Tübingen University hospital, Institute of Pathology, Tübingen, Germany

\subsection{6/ijgc-2021-ESGO.189}

Introduction/Background* Tumor cell dissemination is associated with a less favorable outcome in breast cancer patients. In contrast, only limited clinical significance was yet reported for other gynecologic malignancies. We have previously reported disseminated tumor cells (DTC) not to be associated with established risk factors, L1CAM immunoreactivity and outcome in endometrial carcinoma. It was the aim of this study to investigate potential associations of TCGA-derived molecular features such as POLE-mutation status, p53 abnormalities or MMR deficiency and the presence of DTC in the bone marrow of endometrial carcinoma patients.

Methodology Patients treated for primary endometrial carcinoma at Tuebingen University women's hospital between 2003 and 2016 with bone marrow aspirates and FFPE tumor specimens were identified. For DTC detection, cytospins were stained for pan-cytokeratin (A45-B/B3 antibody). Molecular 
classification was performed according to the Proactive Molecular Risk Classifier for Endometrial Cancer (ProMisE).

Result(s)* A total of 402 patients with a complete set of bone marrow cytology, molecular and clinical data was evaluable. ProMisE molecular classification revealed 40(10.0\%) POLEmut, 103(25,6\%) MMRd, 52(12,9\%) p53-abnormal and $207(51.5 \%)$ tumors with no specific molecular profile (NSMP). Overall DTC were detected in 71/402 (17.7\%) patients. DTC occurrence was distributed equally among molecular groups $(p=0.651)$. DTC were present in $7 / 40$ (17.5\%) POLEmut, 21/103(20.4\%) MMRd, 32/207(15.5\%) NSMP and 11/52(21.2\%) p53 abnormal tumors.

Conclusion* The scientific community widely agrees that molecular classification will be of key importance in future endometrial carcinoma patient care. In line with our previous findings, tumor cell dissemination is not associated with TCGA-inspired molecular groups in our large cohort of primary endometrial carcinoma patients. While DTC are detectable in a significant number of patients, even including cases with favorable POLEmut subtype, tumor cell dissemination seems not to play a role in disease progression and clinical outcome in endometrial carcinoma.

\section{DIAGNOSTIC ACCURACY OF SENTINEL NODE BIOPSY IN NON-ENDOMETRIOID, HIGH-GRADE AND/OR DEEP MYOINVASIVE ENDOMETRIAL CANCER (TRSGO-SLN- 006)}

${ }^{1} \mathrm{D}$ Altın*, ${ }^{2} \mathrm{~S}$ Tașkın, ${ }^{3} \mathrm{~N}$ Tokgözoğlu, ${ }^{4} \mathrm{D}$ Vatansever, ${ }^{5} \mathrm{AH}$ Güler, ${ }^{6} \mathrm{M}$ Gungor, ${ }^{7} \mathrm{~T}$ Tașçı, ${ }^{8} \mathrm{~T}$ Beşe, ${ }^{9} \mathrm{H}$ Turan, ${ }^{10}$ K Kahramanoglu, ${ }^{11} \mathrm{i}$ Yalçın, ${ }^{5} \mathrm{C}$ Celik, ${ }^{8} \mathrm{~F}$ Demirkiran, ${ }^{6} \mathrm{~F}$ Köse, ${ }^{2} \mathrm{FU}$ Ortac, ${ }^{8} \mathrm{M}$ Arvas, ${ }^{12} \mathrm{~A}$ Ayhan, ${ }^{4} \mathrm{C}$ Taskiran. ${ }^{1}$ Ordu Üniversitesi Eğitim ve Araştırma Hastanesi, Turkey; ${ }^{2}$ Ankara Üniversitesi Tip Fakültesi, Turkey; ${ }^{3}$ Prof. Dr. Cemil Taşcıoğlu Şehir Hastanesi, Turkey; ${ }^{4}$ Koc University, Turkey; ${ }^{5}$ Selçuk University, Turkey; ${ }^{6}$ Acıbadem University School of Medicine, Turkey; ${ }^{7}$ Bahçeșehir Üniversite Hastanesi Medical Park Göztepe, Turkey; ${ }^{8}$ Cerrahpaşa Tip Fakültesi, Turkey; ${ }^{9} T$ C Saglik Bakanligi Istanbul Egitim ve Arastirma Hastanesi, Turkey; ${ }^{10}$ Emsey Hastanesi, Turkey; ${ }^{11}$ Ondokuz Mayls University, Turkey; ${ }^{12}$ Başkent Üniversitesi Tıp Fakültesi, Turkey

\subsection{6/ijgc-2021-ESG0.190}

Introduction/Background* The aim of this study was to evaluate sensitivity, negative predictive value (NPV) and false negative rate (FNR) of sentinel lymph node (SLN) mapping algorithm in high-risk endometrial cancer patients.

Methodology Patients with non-endometrioid histology, grade 3 endometrioid tumors and/or tumors with deep myometrial invasion were enrolled in this retrospective, multicenter study. After removal of SLNs, all patients underwent pelvic \pm paraaortic lymphadenectomy. Operations were performed via laparotomy, laparoscopy or robotic surgery. Indocyanine green (ICG) and methylene blue (MB) were used as tracers. SLN detection rate, sensitivity, NPV and FNR were calculated.

Result(s)* Two hundred forty-four patients were included. Surgeries were performed via open approach in 132 (54.1\%) patients. While $92(37.7 \%)$ patients underwent bilateral pelvic lymphadenectomy, 152 (62.3\%) underwent both bilateral pelvic and paraaortic lymphadenectomy. ICG was used in 120 (49.2\%) patients and MB in $124(50.8 \%)$. At least 1 SLN was detected in 222 (91\%) patients with a $65.6 \%$ bilateral detection rate. Fifty-five $(22.5 \%)$ patients had lymphatic metastasis and 45 patients had at least 1 metastatic SLN: 28 macrometastasis, 6 micrometastasis and 11 isolated tumor cells. Lymphatic metastasis was detected by side-specific

\begin{tabular}{|c|c|c|c|}
\hline & Total (244) & $\begin{array}{l}\text { G3 endomet rioid/ } \\
\text { non-endometrioid } \\
\text { (128) }\end{array}$ & $\begin{array}{c}\text { Grade 1-2 } \\
\text { Endometrioid + } \\
\text { Deep MI (116) }\end{array}$ \\
\hline Age, years, median (range) & $63.5(33-87)$ & $63(37-82)$ & $64.5(33-87)$ \\
\hline $\mathrm{BMI}, \mathrm{kg} / \mathrm{m}^{2}$, median (range) & $30(18.6-53)$ & $29.3(19-53)$ & $31.8(18.6-49)$ \\
\hline \multicolumn{4}{|l|}{ Menopausal stat us, $n(\%)$} \\
\hline Premenopause & $20(8.2)$ & $11(8.6)$ & $9(7.8)$ \\
\hline Postmenopause & $224(91.8)$ & $117(91.4)$ & $107(92.2)$ \\
\hline \multicolumn{4}{|l|}{ Surgical route, $n$ (\%) } \\
\hline Laparotomy & $132(54.1)$ & $75(58.6)$ & $57(49.1)$ \\
\hline Laparoscopy & $105(43)$ & $51(39.8)$ & $54(46.6)$ \\
\hline Robotic & $7(2.9)$ & $2(1.6)$ & $5(4.3)$ \\
\hline \multicolumn{4}{|l|}{ Lymphadenectom $\gamma, n(\%)$} \\
\hline BPLND & $92(37.7)$ & $31(24.2)$ & $61(52.6)$ \\
\hline BPPALND & $152(62.3)$ & $97(75.8)$ & $55(47.4)$ \\
\hline \multicolumn{4}{|l|}{ Dye, $n(\%)$} \\
\hline 106 & $120(49.2)$ & $68(53.1)$ & $52(44.8)$ \\
\hline MB & $124(50.8)$ & $60(46.9)$ & $64(55.2)$ \\
\hline Tm size, $\mathrm{mm}$, median (range) & $40(3-130)$ & $40(3-130)$ & $40(8-100)$ \\
\hline \multicolumn{4}{|l|}{ Histology, $n(\%)$} \\
\hline Endometrioid & $182(74.6)$ & $66(51.6)$ & $116(100)$ \\
\hline Serous & $23(9.4)$ & $23(18)$ & \\
\hline Clear cell & $6(2.5)$ & $6(4.7)$ & \\
\hline Carcinosarcoma & $17(7)$ & $17(13.3)$ & \\
\hline Mixed & $10(4.1)$ & $10(7.8)$ & \\
\hline Other & $6(2.5)$ & $6(4.7)$ & \\
\hline \multicolumn{4}{|l|}{ Grade, $n(\%)$} \\
\hline 1 & $34(13.9)$ & & $34(29.3)$ \\
\hline 2 & $82(33.6)$ & & $82(70.7)$ \\
\hline 3 & $128(52.5)$ & $128(0)$ & \\
\hline \multicolumn{4}{|l|}{ Depth of MI, $n(\%)$} \\
\hline None & $8(3.3)$ & $8(6.3)$ & \\
\hline$? 1 / 2$ & $54(22.1)$ & $54(42.2)$ & \\
\hline$>1 / 2$ & $182(74.6)$ & $66(51.6)$ & $116(100)$ \\
\hline \multicolumn{4}{|l|}{ LVSI, n (\%) } \\
\hline Absent & $132(54.1)$ & $64(50)$ & $68(58.6)$ \\
\hline Present & $112(45.9)$ & $64(50)$ & $48(41.4)$ \\
\hline \multicolumn{4}{|l|}{ Cervical stromal invasion, $n(\%)$} \\
\hline Absent & $198(81.1)$ & $96(75)$ & $102(87.9)$ \\
\hline Present & $46(18.9)$ & $32(25)$ & $14(12.1)$ \\
\hline \multicolumn{4}{|l|}{ Stage, $n(\%)$} \\
\hline $\mid A$ & $46(18.9)$ & $46(35.9)$ & \\
\hline IB & $109(44.7)$ & 23 (18) & $86(74.1)$ \\
\hline II & $18(7.4)$ & $10(7.8)$ & $8(6.9)$ \\
\hline\|\| $\mathrm{A}$ & $11(4.5)$ & $10(7.8)$ & $1(0.9)$ \\
\hline IIIC1 & $31(12.7)$ & $19(14.8)$ & $12(10.3)$ \\
\hline $111 \mathrm{C} 2$ & 22 (9) & $14(10.9)$ & $8(6.9)$ \\
\hline IVB & $7(2.4)$ & $6(4.7)$ & $1(0.9)$ \\
\hline Lymphatic met astasis, n (\%) & $55(22.5)$ & $35(27.3)$ & $20(17.2)$ \\
\hline SLN metast asis, $n[\%)$ & 45 (18.4) & $29(22.7)$ & $16(13.8)$ \\
\hline
\end{tabular}

\begin{tabular}{|c|c|c|c|c|}
\hline & \multirow[b]{2}{*}{$\begin{array}{l}\text { SLN Biopsy } \\
\text { Alone }\end{array}$} & \multicolumn{3}{|c|}{ SLN Alg orithm } \\
\hline & & Overall & $\begin{array}{c}\text { Grade } 3 \\
\text { endometrioid/ } \\
\text { non-endometrioid }\end{array}$ & $\begin{array}{c}\text { Grade 1-2 } \\
\text { Endometrioid + } \\
\text { Deep MI }\end{array}$ \\
\hline Sensitivity & $81.8 \%$ & $96.4 \%$ & $97.1 \%$ & $95 \%$ \\
\hline NPV & $95 \%$ & $98.9 \%$ & $98.9 \%$ & $98.9 \%$ \\
\hline FNR & $18.2 \%$ & $3.6 \%$ & $2.9 \%$ & $5 \%$ \\
\hline
\end{tabular}

lymphadenectomy in 8 patients and 2 patients had isolated paraaortic metastasis. Overall sensitivity, NPV and FNR of SLN biopsy were $81.8 \%, 95 \%$ and $18.2 \%$, respectively. By applying SLN algorithm steps, sensitivity and NPV improved to $96.4 \%$ and $98.9 \%$, respectively. For grade 3 tumors, sensitivity, NPV and FNR of the SLN algorithm were 97.1\%, 98.9\% and 2.9\%, respectively. Sensitivity, NPV and FNR of SLN algorithm were 95\%, 98.9\% and 5\%, respectively in deep myoinvasive tumors.

Conclusion* This study was performed in one of the largest high-risk endometrial cancer population. SLN algorithm was found to be safe and had high diagnostic accuracy also in high-risk endometrial cancer patients. Although it seems like SLN algorithm is a feasible option for staging, long term studies to determine impact of SLN biopsy alone on survival are needed before it becomes standard of care in high-risk endometrial cancer. 